\title{
Involvement of adipose tissue inflammation and dysfunction in virus-induced type 1 diabetes
}

\author{
James C Needell, Madalyn N Brown and Danny Zipris* \\ Barbara Davis Center for Childhood Diabetes, University of Colorado Denver, Aurora, Colorado, USA \\ Correspondence should be addressed to D Zipris: zdanny@innatebiotechnologies.com \\ *(D Zipris is now at Innate Biotechnologies LLC, Denver, Colorado, USA)
}

\section{Abstract}

The etiopathogenesis of type 1 diabetes (T1D) remains poorly understood. We used the LEW1.WR1 rat model of Kilham rat virus (KRV)-induced T1D to better understand the role of the innate immune system in the mechanism of virus-induced disease. We observed that infection with KRV results in cell influx into visceral adipose tissue soon following infection prior to insulitis and hyperglycemia. In sharp contrast, subcutaneous adipose tissue is free of cellular infiltration, whereas $\beta$ cell inflammation and diabetes are observed beginning on day 14 post infection. Immunofluorescence studies further demonstrate that KRV triggers CD68+ macrophage recruitment and the expression of KRV transcripts and proinflammatory cytokines and chemokines in visceral adipose tissue. Adipocytes from naive rats cultured in the presence of KRV express virus transcripts and upregulate cytokine and chemokine gene expression. KRV induces apoptosis in visceral adipose tissue in vivo, which is reflected by positive TUNEL staining and the expression of cleaved caspase-3. Moreover, KRV leads to an oxidative stress response and downregulates the expression of adipokines and genes associated with mediating insulin signaling. Activation of innate immunity with Poly I:C in the absence of KRV leads to $\mathrm{CD} 68^{+}$macrophage recruitment to visceral adipose tissue and a decrease in adipokine expression detected 5 days following Poly $(\mathrm{I}: \mathrm{C})$ treatment. Finally, proof-ofprinciple studies show that brief anti-inflammatory steroid therapy suppresses visceral adipose tissue inflammation and protects from virus-induced disease. Our studies provide evidence raising the hypothesis that visceral adipose tissue inflammation and dysfunction may be involved in early mechanisms triggering $\beta$ cell autoimmunity.

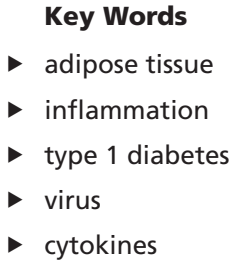

Journal of Endocrinology (2018) 238, 61-75

\section{Introduction}

Type 1 diabetes (T1D) is a proinflammatory progressive disease thought to be triggered by both genetic and environmental factors (Atkinson et al. 2014). There is evidence supporting the notion that viruses are key players in disease mechanisms, but data establishing a cause-and-effect relationship between virus infections and T1D humans are currently lacking (Kondrashova
\& Hyöty 2014, Morgan \& Richardson 2014, de Beeck \& Eizirik 2016, Lönnrot et al. 2017).

The LEW1.WR1 rat develops insulitis and diabetes 2-4 weeks following viral infection, with a disease rate of $\sim 60 \%$ (Hara et al. 2012). Kilham rat virus (KRV)-induced diabetes is rat and strain specific and closely resembles the human disorder with respect to histopathology, 
pathogenesis, lack of gender bias, the involvement of $\mathrm{CD}^{+}$and $\mathrm{CD}^{+} \mathrm{T}$ cells in disease pathogenesis and major histocompatibility complex (MHC) association (Mordes et al. 2004). Thus, it is an ideal model for studying the cellular and molecular mechanisms involved in virusinduced disease (Mordes et al. 2004).

We recently implicated the innate immune system in the mechanisms of KRV-induced T1D development in the LEW1.WR1 rat (Zipris et al. 2005, 2007, Londono et al. 2010, Hara et al. 2012, 2013, 2014, Needell et al. 2017). In the course of our studies, we observed that infection of LEW1.WR1 rats with KRV induces cell influx into adipose tissue detected on day 5 post infection prior to $\beta$ cell inflammation and hyperglycemia (this manuscript). Because microbes can directly infect adipocytes and induce systemic inflammation and metabolic dysregulation (Schäffler \& Schölmerich 2010), and given the wellestablished link between adipose tissue inflammation and mechanisms triggering type 2 diabetes (Hotamisligil et al. 1995, Blüher 2013, Han \& Levings 2013, Haase et al. 2014, Romacho et al. 2014, Hong et al. 2015), we were interested in better understanding the role of KRVinduced adipose tissue inflammation in the development of T1D in the LEW1.WR1 rat. Our data demonstrate for the first time that infection with a diabetogenic virus leads to $\mathrm{CD} 68^{+}$macrophage infiltration into visceral but not subcutaneous adipose tissue observed as early as $24 \mathrm{~h}$ following infection. Furthermore, this cell infiltration is accompanied by the expression of proinflammatory cytokines and chemokines and adipose tissue dysfunction. Proof-of-principle studies indicate that steroid therapy downregulates visceral adipose tissue inflammation and attenuates T1D development. Our data raise the hypothesis that visceral adipose tissue inflammation and dysfunction may be involved in early mechanisms that trigger T1D.

\section{Materials and methods}

\section{Animals and viruses}

Specific pathogen-free LEW1.WR1 rats of both sexes were obtained from BRM Inc. (Worcester, MA, USA). Animals were bred and housed in a specific pathogen-free facility and maintained in accordance with the Guide for the Care and Use of Laboratory Animals (Institute of Laboratory Animal Resources, National Research Council, National Academy of Sciences, 1996) and the guidelines of the Institutional Animal Care and Use Committee of the
University of Colorado Denver. All rat protocols used in this study were approved by the Institutional Animal Care and Use Committee of the University of Colorado Denver. KRV was propagated and tittered as previously described (Zipris et al. 2005).

\section{Virus, Poly (I:C) and dexamethasone treatment protocols}

For diabetes induction, female and male rats aged 21-25 days were injected i.p. with $1 \times 10^{7} \mathrm{PFU}$ of KRV as previously described (Zipris et al. 2005). Rats treated with PBS were used as a control. To examine the effect of innate immune activation on T1D development and adipose tissue inflammation, rats were i.p. injected with $3 \mu \mathrm{g} / \mathrm{g}$ body weight of Poly (I:C) (Sigma-Aldrich) on 3 consecutive days or were treated with $3 \mu \mathrm{g} / \mathrm{g}$ body weight of Poly (I:C) on 3 consecutive days and infected with $1 \times 10^{7} \mathrm{PFU}$ of KRV on the following day. Dexamethasone was purchased from MBL International (Woburn, MA, USA). Animals were killed, and adipose tissue and pancreases were recovered at different time points after treatment. Groups of animals injected with KRV only or Poly (I:C) plus KRV were administered $0.2 \mu \mathrm{g} / \mathrm{g}$ body weight of dexamethasone. Diabetes was defined as the presence of a plasma glucose concentrations $>250 \mathrm{mg} / \mathrm{dL}$ $(11.1 \mathrm{mM} / \mathrm{L})$ on 2 consecutive days. Rats were monitored for T1D development for 40 days following infection.

\section{Histological analysis and fluorescence microscopy of adipose tissue and pancreases}

To assess cellular infiltration, tissue was fixed for $24 \mathrm{~h}$ in $10 \%$ neutral-buffered formalin, embedded in paraffin, cut $(5-6 \mu \mathrm{m})$ and mounted on microscope slides and subsequently stained with hematoxylin-eosin.

For immunohistochemistry analyses, sections of formalin-fixed, paraffin-embedded tissue was mounted on slides, deparaffinized in xylene and then rehydrated with distilled $\mathrm{H}_{2} \mathrm{O}$ through graded alcohols. Antigen retrieval was enhanced by microwaving the slides in citrate buffer $(\mathrm{pH}$ 6). All secondary antibodies used in these analyses were polyclonal obtained from Jackson ImmunoResearch. For CD68 staining, we used a mouse anti-rat CD68 monoclonal antibody (mouse IgG1, clone ED1, Bio-Rad) followed by incubation with donkey anti-mouse IgG $(\mathrm{H}+\mathrm{L})$-Cy3 or a donkey anti-mouse IgG $(\mathrm{H}+\mathrm{L})$ conjugated to Alexa 488. Adipocytes were detected using rabbit anti-Perilipin A (Santa Cruz) followed by 
incubation with donkey anti-rabbit $\operatorname{IgG}(\mathrm{H}+\mathrm{L})$ conjugated to Alexa 488 or donkey anti-rabbit IgG $(\mathrm{H}+\mathrm{L})$ conjugated to Cy3. Insulin staining was performed using guinea pig anti-rat insulin (Abcam) and FITC-conjugated donkey anti-guinea pig $\operatorname{IgG}(\mathrm{H}+\mathrm{L})$ or Cy3-conjugated donkey anti-guinea pig $\operatorname{IgG}(\mathrm{H}+\mathrm{L})$. IL-1 $\beta$ expression was assessed with rabbit anti-rat IL-1 $\beta$ (Bioss, Woburn, MA, USA) and donkey anti-rabbit IgG $(\mathrm{H}+\mathrm{L})-\mathrm{Cy} 3$. For p22phox staining, we used a rabbit anti-rat p22phox (Santa Cruz) and donkey anti-rabbit IgG $(\mathrm{H}+\mathrm{L})$-Alexa 488. Apoptosis was evaluated with a TUNEL staining kit (Roche Applied Science) and rabbit anti-cleaved caspase-3 (Cell Signaling) plus donkey anti-rabbit IgG $(\mathrm{H}+\mathrm{L})$-Cy3. Superoxide production was evaluated with dihydroethidium (DHE) from Cayman. 4',6-Diamidine-2'-phenylindole dihydrochloride (DAPI) was added to slides prior to mounting with cover slips.

Tissue section staining was analyzed using an Olympus BX51-TRF Microscope BX51 (Olympus) equipped with a Penguin Pro-150ES Camera system (Pixera, Los Gatos, CA, USA).

\section{Adipocyte isolation}

Visceral adipose tissue was minced and digested in $0.1 \%(\mathrm{w} / \mathrm{v})$ collagenase type I (Sigma-Aldrich) at $37^{\circ} \mathrm{C}$ for $1 \mathrm{~h}$ with gentle agitation (Matsumoto et al. 2008). After filtration and centrifugation, the floating top layer containing adipocytes was collected. Viability was assessed by a trypan blue exclusion test and was $>95 \%$. Fifty thousand cells were cultured in the presence or absence of $1 \times 10^{6} \mathrm{PFU} / \mathrm{mL}$ KRV for $5 \mathrm{~h}$.

\section{RNA extraction, cDNA synthesis, quantitative RT-PCR and Western blotting}

RNA extraction, cDNA synthesis and quantitative RT-PCR were performed as previously described (Hara et al. 2012).

To assess the level of adiponectin, adipose tissue was lysed and $100 \mu \mathrm{g}$ protein were loaded onto $14 \%$ SDS-PAGE gels for electrophoresis. After separation and transfer, the membrane was probed with anti-GAPDH rabbit polyclonal Ab (Santa Cruz) or with a rabbit monoclonal anti-adiponectin (Cell Signaling). The membranes were then exposed to biotin-conjugated goat anti-rabbit IgG $(\mathrm{H}+\mathrm{L})$ followed by incubation with peroxidase-conjugated streptavidin (both from Jackson ImmunoResearch). The blots were developed using the Pierce ECL Western Blotting Substrate from Thermo Fisher. Gel data were quantified using densitometry with ImageJ.

\section{Statistical analysis}

Statistical comparisons of diabetes-free survival among groups were performed using the method of Kaplan and Meier. Comparisons between more than two groups were performed with a one-way ANOVA with Bonferroni's multiple comparison test. Comparisons between two groups were performed with unpaired Student's $t$-test.

\section{Results}

Virus infection induces cellular infiltration into visceral adipose tissue prior to $\beta$ cell inflammation

We sought to better understand the timing and tissue specificity of the cellular infiltration detected in visceral adipose tissue from infected animals. For this purpose, LEW1.WR1 rats were injected with KRV or PBS (control), and visceral and subcutaneous adipose tissue and pancreases were removed at different time points following KRV inoculation; tissue sections were stained with hematoxylin and eosin $(n \geq 5)$. Figure $1 \mathrm{~A}$ and $\mathrm{B}$ suggest a massive influx of nucleated cells into visceral adipose tissue present in the interstitial space surrounding adipocytes from day 5 infected animals. In contrast, control rats administered PBS do not display signs of cellular infiltration in visceral fat tissue. Furthermore, Fig. $1 \mathrm{~A}$ suggests that infiltration of cells into adipose tissue was evident as early as day 1 post infection and was also detected on days 14 and 40 at the times when insulitis and diabetes are typically detected and when the experiments are terminated, respectively. In sharp contrast to adipose tissue, subcutaneous white adipose tissue was found to be free of cell infiltration on days 1, 5, 14 and 40 following virus inoculation (Fig. 1B and data not shown).

Next, we tested the hypothesis that innate immune activation with Poly (I:C) in the absence of KRV can induce cellular infiltration into visceral adipose tissue, as seen following virus infection. To this aim, animals were administered Poly (I:C) only on 3 consecutive days at doses that by themselves do not lead to diabetes but that in conjunction with KRV, exacerbate disease development (Londono et al. 2010). Figure 1C demonstrates that Poly (I:C) treatment leads to a substantial cellular influx into visceral adipose tissue observed 5 days following Poly (I:C) treatment. As expected, visceral adipose tissue from animals injected with Poly (I:C) plus KRV exhibited cell infiltration into visceral adipose tissue on day 5 post infection. 


\begin{tabular}{|l|l|l|r|r|}
\hline $\begin{array}{l}\text { Journal of } \\
\text { Endocrinology }\end{array}$ & J C Needell et al. & $\begin{array}{l}\text { Adipose tissue inflammation in } \\
\text { type } 1 \text { diabetes }\end{array}$ & $\mathbf{2 3 8 : 1}$ & $\mathbf{6 4}$ \\
\hline
\end{tabular}

A

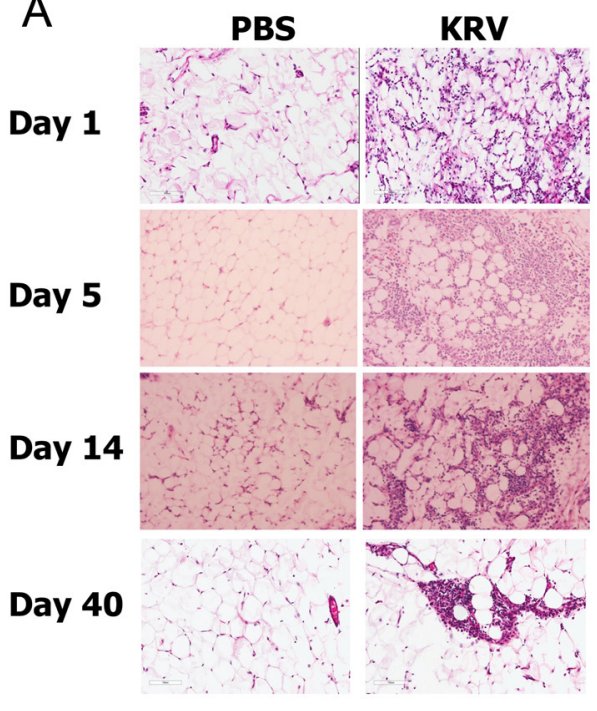

B

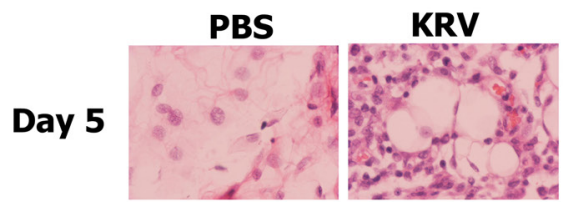

C

PBS

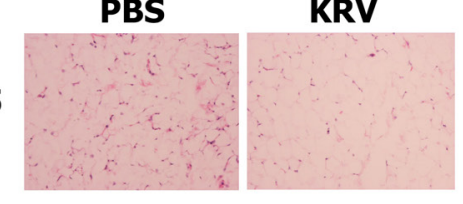

Day 5

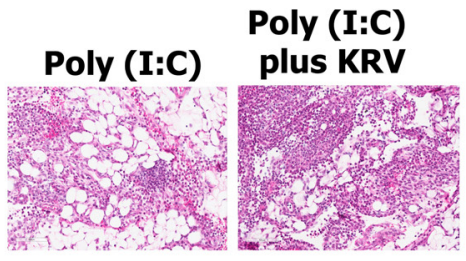

E

PBS
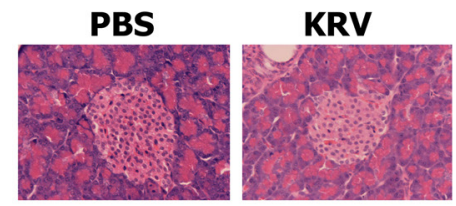

Insulitis

Day 14
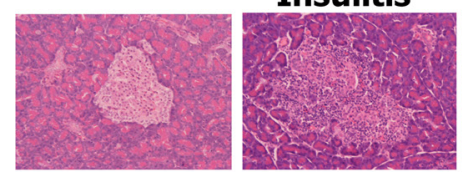

\section{Diabetes}

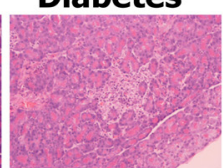

\section{Figure 1}

Infection with KRV leads to cell infiltration into visceral adipose tissue. LEW1.WR1 rats at 21-25 days of age of either sex were injected i.p. with either PBS (control), $1 \times 10^{7}$ PFUs of KRV, $3 \mu \mathrm{g} / \mathrm{g}$ body weight of Poly (I:C) on 3 consecutive days or $3 \mu \mathrm{g} / \mathrm{g}$ body weight of Poly (I:C) on 3 consecutive days plus $1 \times 10^{7} \mathrm{PFU}$ s of KRV injected on the following day. Rats were tested for diabetes for 40 days following viral inoculation. Diabetes was defined as the presence of plasma glucose concentrations $>250 \mathrm{mg} / \mathrm{dl}(11.1 \mathrm{mmol} / \mathrm{L})$ on 2 consecutive days. Tissue sections were stained with hematoxylin and eosin. Shown are visceral fat tissue sections removed from control and KRV-infected rats at the indicated time points following infection using $\times 10$ (A) and $\times 40$ (B) objectives. Also shown are subcutaneous adipose tissue sections from control and day 5 -infected rats using a $\times 10$ objective (C), visceral adipose tissue sections from day 5 -treated rats administered with Poly $(I: C)$ or Poly $(I: C)$ plus KRV as indicated using a $\times 10$ objective (D) and pancreases from control and KRV-infected rats removed at the indicated time points following infection using a $\times 20$ objective $(E)$. The data are representative of images obtained from $\geq 5$ independent experiments. KRV, Kilham rat virus. A full color version of this figure is available at https://doi.org/10.1530/JOE-18-0131.

Figure 1D further shows that unlike visceral adipose tissue, the exocrine tissue and $\beta$ cells from day 5 -infected animals are insulitis free, whereas $\beta$ cells from day 14-infected animals are inflamed or show signs of tissue destruction. Pancreases from control rats injected with PBS are insulitis free at all times.

Collectively, the data suggest that KRV induces cellular infiltration into visceral but not subcutaneous adipose soon after infection and prior to $\beta$ cell inflammation and diabetes.

\section{KRV induces infiltration of $\mathrm{CD} 68^{+}$macrophages into visceral adipose tissue}

We tested the hypothesis that KRV induces macrophage infiltration into visceral adipose tissue. Rats were infected with KRV or were injected with PBS $(n \geq 5)$. Visceral adipose tissue and pancreases were removed on days 5 and 14 following infection. Subsequently, the tissue sections were stained with antibodies against CD68 and Perilipin A for the identification of macrophages and adipocytes, respectively. Antibodies against insulin were used for detecting insulin-producing $\beta$ cells. The data presented in Fig. 2A show that visceral adipose tissue from uninfected rats stained with Perilipin A but not anti-CD68 antibodies. In contrast, CD68 expression was readily detectable in visceral adipose tissue at days 5 and 14 following infection (Fig. 2A). Furthermore, areas with cellular infiltration and no visible Perilipin A staining could be observed in visceral adipose tissue from infected rats on days 5 and 14 (Fig. 2A). Unlike visceral adipose tissue, staining for CD68 was not detectable in the exocrine tissue or $\beta$ cells from day 5-infected rats (Fig. 2B and C). The data imply that KRV induces the infiltration of $\mathrm{CD} 68^{+}$macrophages 
A

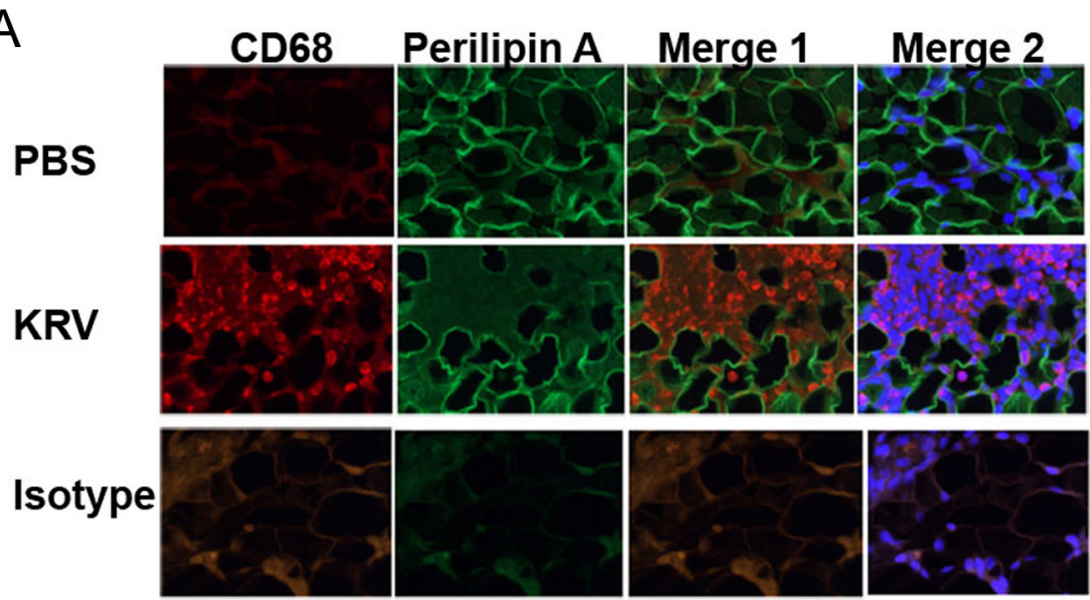

B

PBS
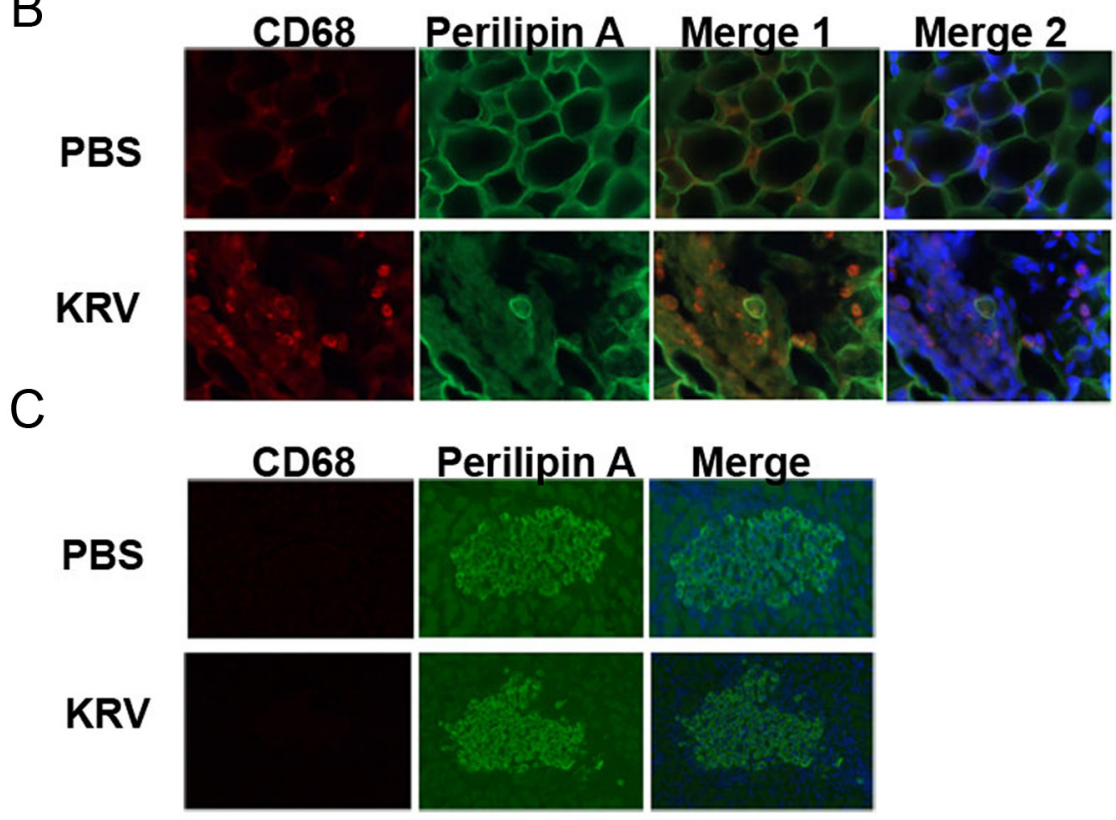

Figure 2

KRV induces macrophage recruitment to visceral adipose tissue. LEW1.WR1 rats were injected with PBS (control) or KRV, and adipose tissue and pancreases were removed at different time points following infection $(n \geq 5)$. Shown are immunofluorescence images of visceral adipose tissue from day 5 (A) and day 14 (B) infected and uninfected rats stained with antibodies against the macrophage and adipocyte markers CD68 (red) and Perilipin A (green), respectively, using a $\times 20$ objective. Merge 1 and merge 2 represent the co-localization of red and green versus red, green and blue staining, respectively. Shown in Panel (C) are pancreatic sections stained from day 5 infected and uninfected rats stained with antibodies against CD68 (red) and insulin (green). The data are representative of images obtained from $\geq 5$ independent experiment. KRV, Kilham rat virus. A full color version of this figure is available at https://doi.org/10.1530/JOE-18-0131.

into visceral adipose tissue, which is observed early after infection.

\section{KRV upregulates proinflammatory cytokines and chemokines in visceral but not subcutaneous adipose tissue}

The observation that infection with KRV results in macrophage recruitment to visceral adipose tissue prompted us to test the hypothesis that KRV induces the expression of proinflammatory cytokines and chemokines in visceral adipose tissue. To this end, we measured the levels of transcripts for cytokine and chemokine genes, we have previously implicated in KRV-induced T1D in the LEW1.WR1 rat (Wolter et al. 2009), i.e., Il1b, IL-1 receptor antagonist (Il1rn), Il18, Tnfa, Il10, Ifng, Cxcl10,
Il6, Ccl2, Ccl5, Cxcl10, Irf7 and Stat1, in visceral and subcutaneous adipose tissue on days 5 and 14 following virus inoculation. To address KRV infectivity and replication in adipose tissue, we measured the level of KRV transcripts in visceral and subcutaneous white adipose tissue. Tissues from rats that received PBS were used as a control $(n=4-6)$. The data shown in Fig. 3A suggest that both visceral and subcutaneous adipose tissue from day 5 -infected rats express transcripts for KRV $(P<0.001$ and $P<0.05$, respectively, vs the uninfected control), albeit the expression level of KRV transcripts was considerably higher in visceral compared with subcutaneous adipose tissue. We further revealed that infection with KRV induces a 10to 20-fold increase in the level of transcripts for Il1rn, Irf7 $(P<0.001$ vs uninfected for both genes) and Ifng $(P<0.01$ vs uninfected). A five- to ten-fold increase in transcript levels 
A

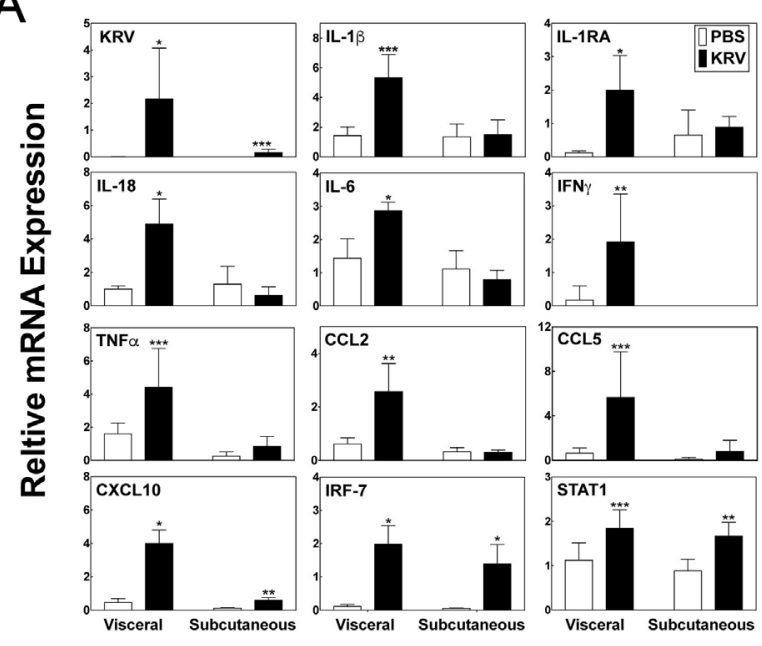

D
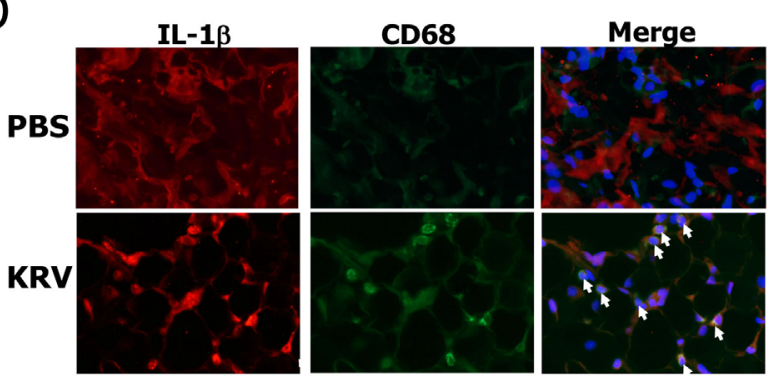

B

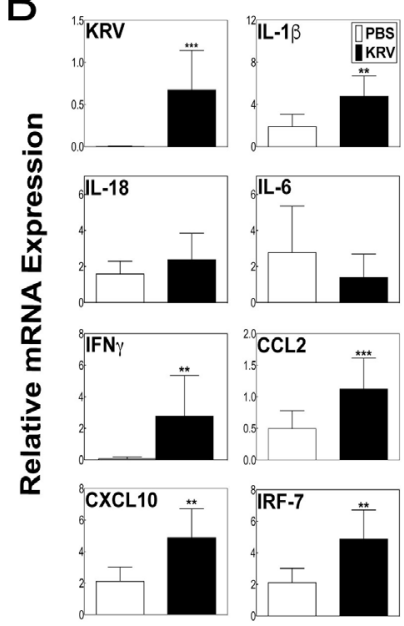

C

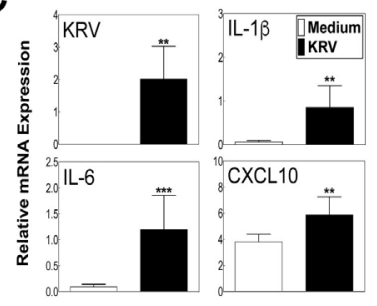

E
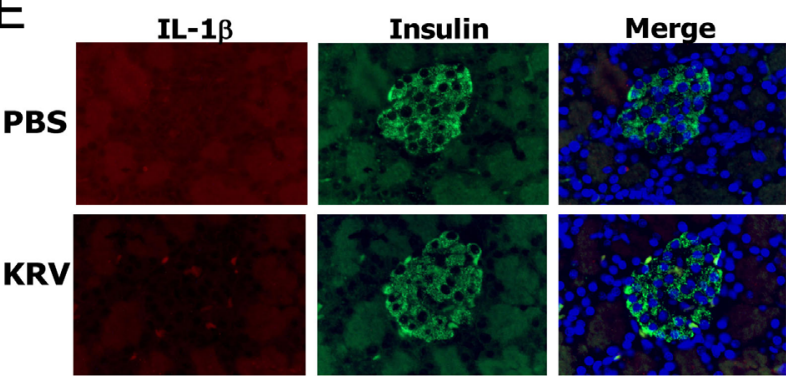

Figure 3

KRV upregulates proinflammatory cytokines and chemokines in visceral adipose tissue in vivo and in adipocytes in vitro. LEW1.WR1 rats at 21-25 days of age were left uninfected or were treated with KRV. For assessing proinflammatory cytokine and chemokine expression in vivo, visceral and/or subcutaneous fat tissue was removed from control uninfected and virus-infected rats $(n=4-6)$. For evaluating KRV-induced cytokine expression in vitro, visceral adipocytes were isolated from naive rats and cultured in the presence or absence of KRV for $5 \mathrm{~h}(n=3-6)$. RNA was extracted from fat tissue and adipocytes and the expression levels of the indicated genes were assessed using quantitative RT-PCR. Data are expressed as the mRNA expression of the gene of interest relative to the expression of $\beta$-actin. The results presented in panel A are from visceral and subcutaneous adipose tissue removed 5 days following infection. Panel B includes observations from visceral adipose tissue obtained from day 14 infected rats. Panel C displays data from adipocytes cultured in the presence or absence of KRV. Bars represent the mean value \pm S.D. Also shown are paraffin sections of visceral fat (D) and pancreatic (E) tissue sections from PBS and LEW1.WR1 rats on day 5 post infection stained with antibodies against IL-1 $\beta$ and CD68 or IL-1 $\beta$ and insulin, as indicated in the figure, using a $\times 20$ objective $(n=3)$. Merge 1 and merge 2 represent the co-localization of red and green versus red, green and blue staining, respectively. White arrows indicate cells expressing CD68 plus IL-1 $\beta$. Histological data are representative of images obtained from 3 to 5 independent experiments. Statistical comparisons between PBS- vs KRV-treated rats were performed using an unpaired Student's $t$-test. ${ }^{*} P<0.001 ; * * P<0.01$; $* * * P<0.05$. KRV, Kilham rat virus. A full color version of this figure is available at https://doi.org/10.1530/JOE-18-0131.

was observed for Ccl5 $(P<0.05)$, Cxcl10 and Il18 $(P<0.001$ for both). Lastly, a two- to four-fold increase was observed in the levels of mRNA for Ccl2 $(P<0.01)$, Il6 $(P<0.001)$, $I l 1 b$, Tnfa and Stat $1(P<0.05$ for all three genes). In sharp contrast, transcript levels for most of these genes were not altered in subcutaneous adipose tissue. Elevated transcript levels in this tissue were observed only for Irf7 $(P<0.001)$, Stat1 and Cxcl10 ( $P<0.01$ for the latter genes). The results shown in Fig. 3B further indicate that KRV mRNA was also readily detectable in visceral adipose tissue on day 14 following infection ( $P<0.05$ vs uninfected). Moreover, we observed a 30 -fold increase in the level of transcripts for Ifng $(P<0.01)$ and a two- to three-fold increase in
Il1b, Cxcl10, Stat1 $(P<0.01$ for all three), and Ccl2 $(P<0.05)$ in visceral adipose tissue from day 14-infected rats vs the control.

Because KRV induces a robust innate immune upregulation in visceral adipose tissue, we checked whether KRV can directly infect adipocytes and induce cytokine expression in adipocytes in vitro. Adipocytes were isolated from visceral adipose tissue from naive LEW1.WR1 rats and were cultured in the absence or presence of KRV $(n=3-6)$, and RNA was isolated $5 \mathrm{~h}$ later. The quantitative RT-PCR data shown in Fig. 3C demonstrate that KRV transcripts can be detected in adipocytes incubated in the presence of the virus $(P<0.01$ 
vs uninfected). The data also indicate that activation of adipocytes with KRV in vitro leads to a 13-fold increase in the level of transcripts for $I l 1 b$ and $I l 16(P<0.01$ and $P<0.05$, respectively) and a 1.5 -fold increase in the level of Cxcl10 mRNA $(P<0.01)$ compared with the control.

Immunofluorescence was further used to corroborate the RT-PCR data implying that KRV induces IL-1 expression in visceral adipose tissue. For this purpose, adipose and pancreatic tissues were removed on day 5 post infection and subsequently stained with antibodies against IL-1 $\beta$ and CD68 $(n=3)$. Figure 3C presents data confirming that IL- $1 \beta$ is detectable in visceral adipose tissue from infected rats and is expressed by $\mathrm{CD}^{+} 8^{+}$macrophages. Unlike visceral adipose tissue from infected rats, staining for IL-1 $\beta$ and CD68 was not detectable in visceral adipose tissue from control uninfected animals or pancreatic $\beta$ cells and exocrine tissue from day 5-infected or -uninfected rats (Fig. 3C and D).

Taken together, these observations suggest that infection with KRV leads to cytokine and chemokine upregulation in visceral adipose tissue associated with the expression of IL-1 $\beta$ in macrophages on day 5 after virus infection, prior to $\beta$ cell inflammation or hyperglycemia. The data also imply that KRV can infect adipocytes and induce cytokine and chemokine gene upregulation in adipocytes in vitro.

\section{KRV induces an oxidative stress response in visceral adipose tissue}

Previous reports have implicated viral infections as a mechanism of inducing an oxidative stress response (Olagnier et al. 2014, Reshi et al. 2014). Moreover, oxidative stress signaling has been implicated as a mechanism of obesity-induced insulin resistance and T2D (Furukawa et al. 2004, Picklo et al. 2012, Han 2016). We examined the hypothesis that KRV induces oxidative stress pathways in visceral adipose tissue. To test this possibility, we used three experimental approaches. First, we analyzed the expression of p22phox, a subunit of NADPH oxidase that mediates the production of ROS (Espinosa-Diez et al. 2015). Because p22phox may be expressed by macrophages (Casbon et al. 2009), we addressed the possibility that p22phox is expressed in $\mathrm{CD}^{+} 8^{+}$macrophages from inflamed adipose tissue. Second, we used DHE to detect superoxide production. Third, we assessed the level of transcripts for genes associated with promoting or downmodulating oxidative stress pathways. The data shown in Fig. 4A indicate that $\mathrm{p} 22^{\text {phox }}$ protein was minimally expressed
A

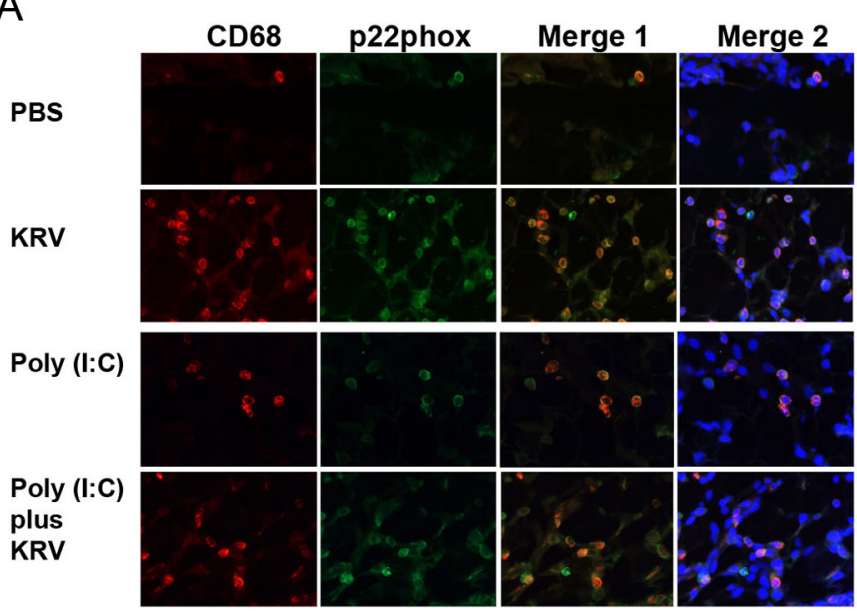

B

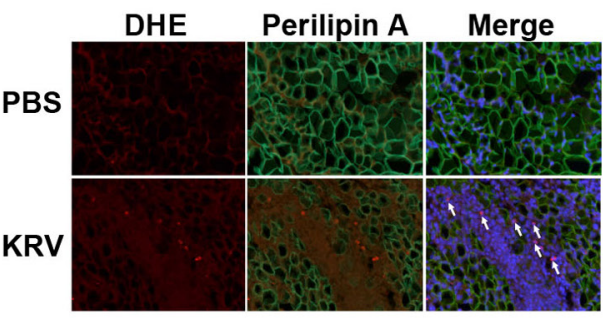

C
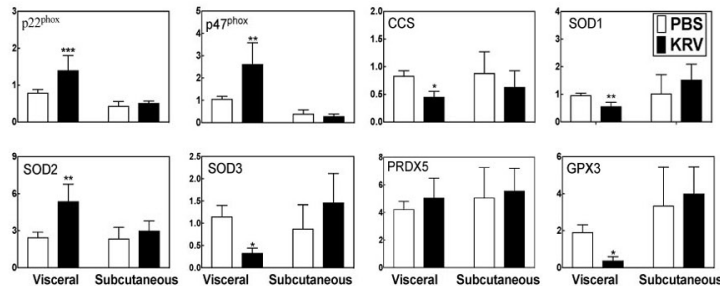

\section{Figure 4}

KRV induces an oxidative stress response in visceral adipose tissue. Rats were injected with PBS or KRV or treated with Poly (I:C) only or Poly (I:C) plus KRV, and tissue was removed on day 5 post infection. Shown in Panel A are paraffin sections of visceral adipose tissue from rats given the different treatments as indicated stained with antibodies against CD68 (red) and p22 phox (green) $(n=3)$. Merge 1 and merge 2 represent the co-localization of red and green vs red, green and blue staining, respectively. Shown in panel B are immunofluorescence images of visceral adipose tissue stained with dihydroethidium (DHE) (red) and Perilipin A (green), and a merge of DHE, Perilipin A and DAPI (blue). Images of fat tissue sections were obtained using a $\times 20$ objective. Panel $C$ shows the expression level of transcripts for genes associated with oxidative stress pathways in the indicated adipose tissue evaluated by quantitative RT-PCR $(n=5-6)$. White arrows indicate sites with ROS. Bars represent mean values \pm s.D. Histological sections shown are representative of images obtained from 3 to 5 independent experiments. Statistical analysis was performed using an unpaired Student's $t$-test. ${ }^{*} P<0.001 ; * * P<0.01 ; * * * P<0.05$. DHE, dihydroethidium; KRV, Kilham rat virus. A full color version of this figure is available at https://doi.org/10.1530/ JOE-18-0131. 
in visceral adipose tissue from control PBS-injected rats, whereas p22phox was readily observed in adipose tissue from day 5 -infected rats $(n=3)$. The data further show that p22phox is primarily expressed by $\mathrm{CD} 68^{+}$macrophages. Our findings also show that activation of the innate immune system with Poly (I:C) in the absence of KRV also leads to infiltration of $\mathrm{CD} 8^{+}$macrophages expressing p22phox in visceral adipose tissue. Visceral adipose tissue from rats injected with Poly (I:C) plus KRV was also positive for the expression of both CD68 and p22phox. Consistent with these data, visceral adipose tissue from day 5-infected rats $(n=3)$ exhibited positive staining for ROS (Fig. 4B), whereas tissue from uninfected rats was ROS free, suggesting that ROS are produced in parallel with visceral adipose tissue inflammation.

The RT-PCR data presented in Fig. 4C $(n=5-6)$ indicate that infection with KRV leads to a two-fold increase in the expression level of transcripts for the NADPH oxidase subunits $p 22^{\text {phox }}$ and $p 47^{\text {phox }}$ compared with uninfected animals $(P<0.05$ and $P<0.01$, respectively). In contrast, KRV induces a two- to five-fold decrease in the level of transcripts for genes associated with mechanisms of superoxide detoxification (Espinosa-Diez et al. 2015), i.e., copper chaperone for SOD1 (Ccs), glutathione peroxidase $3(G p \times 3)$, superoxide dismutase 3 ( $\operatorname{Sod} 3)$ $(P<0.001$ for all three genes) and Sod1 $(P<0.01)$, and no change in peroxiredoxin-5 ( $\operatorname{Pr} d x 5)$. Only the level of Sod2 mRNA was elevated two-fold in visceral adipose tissue from infected rats compared with the control $(P<0.01)$. No significant changes in the expression of these genes were observed in subcutaneous adipose tissue from infected animals. Taken together, these data imply that KRV induces an oxidative stress response and ROS production and downregulates antioxidant pathways in visceral adipose tissue from LEW1.WR1 rats.

\section{KRV induces apoptosis in visceral adipose tissue}

Viral infection and cytokines such as TNF $\alpha$, IL-1 $\beta$ and IFN- $\gamma$ have been associated with mechanisms that trigger apoptosis (Arstall et al. 1999, Anne Roulston et al. 1999, Kishimoto et al. 2002, Aggarwal 2003). Moreover, apoptosis in adipose tissue has been implicated as a mechanism of T2D progression (Alkhouri et al. 2010). Thus, we examined the possibility that KRV induced apoptosis in inflamed visceral adipose tissue in the course of disease progression. Animals were administered PBS or KRV, and adipose tissue was removed on day 5 post infection and subsequently subjected to TUNEL assays $(n=3-5)$. The data shown in Fig. 5A, obtained following staining with TUNEL combined with antibodies against Perilipin A or anti-CD68, suggest that TUNEL and CD68-positive cells are not present in adipose tissue from uninfected animals. In sharp contrast, TUNEL and CD68 positivity could be detected in adipose tissue from day 5 -infected animals. Figure 5B further indicates that TUNEL positivity in adipose tissue from infected animals was not associated with CD68 staining. Finally, data shown in Fig. 5C suggest that islet cells from day 5 -infected rats do not show TUNEL or CD68 positivity.

To gain insight into mechanisms by which KRV induces apoptosis in visceral adipose tissue, we analyzed the expression of activated caspase-3, which is a key effector caspase linked with apoptosis induction (Budihardjo et al. 1999). Quantitative RT-PCR was used to assess the expression level of the proapoptotic genes Bax and Bid vs Fas, which mediate the intrinsic and extrinsic apoptosis signaling pathways, respectively (Desagher et al. 1999, Wei et al. 2000, Cheng et al. 2001, Zong et al. 2001). RT-PCR was also used to assess the level of transcripts for inducible nitric oxide synthetase 2 (Inos2) and caspase-8 (Casp8), which have been implicated in triggering and executing programmed cell death, respectively (Brune 2003, Strasser et al. 2011). Figure 5D shows that consistent with the TUNEL data, activated caspase-3 was detected in visceral adipose tissue from day 5 -infected rats and co-localized with the nucleus, whereas adipose tissue from uninfected animals was found to be negative for cleaved capase- 3 staining ( $n=3-5)$. Lastly, RT-PCR analysis indicated that compared with uninfected rats, KRV induces a significant $\sim 1.5$ - to 3.5 -fold increase in the level of the pro-apoptotic genes BCL2-associated X (Bax), BH3 interacting-domain death agonist (Bid) $(P<0.01$ for both), Fas, Casp8 $(P<0.05$ for both) and Inos2 $(P<0.001)(n=5-6)$ (Albina et al. 1993, Sarih et al. 1993, Nikoletopoulou et al. 2013).

Collectively, these data suggest that KRV-induced inflammation in visceral adipose tissue is accompanied by the induction of apoptotic cell death pathways in the days following virus inoculation.

Infection with KRV downregulates the expression of adipokines and genes linked with insulin signaling pathways

Given our findings that infection with KRV leads to a robust proinflammatory response, oxidative stress and apoptosis in visceral adipose tissue (this manuscript) and since adipose tissue dysfunction has been associated with mechanisms of T2D (Mittendorfer 2011), we investigated the effect of KRV infection and innate immune activation 
A
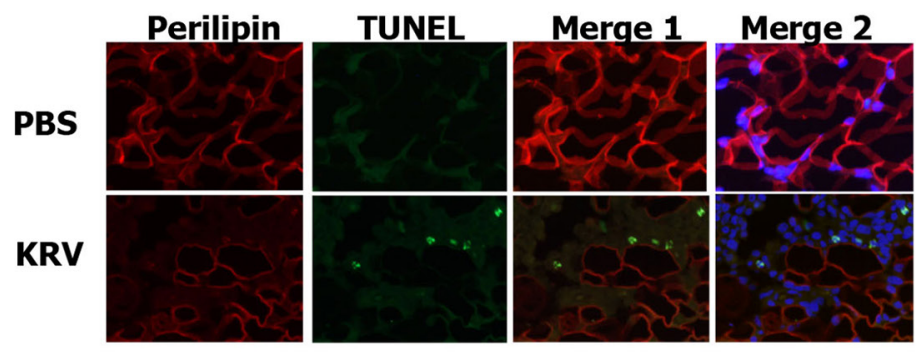

B

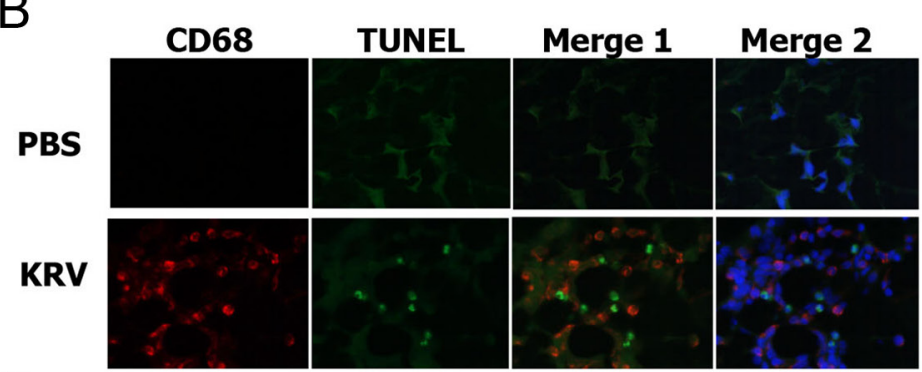

C

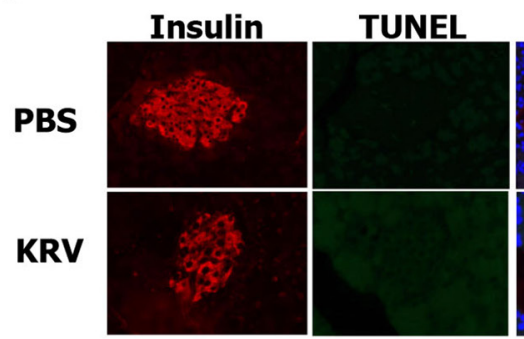

D

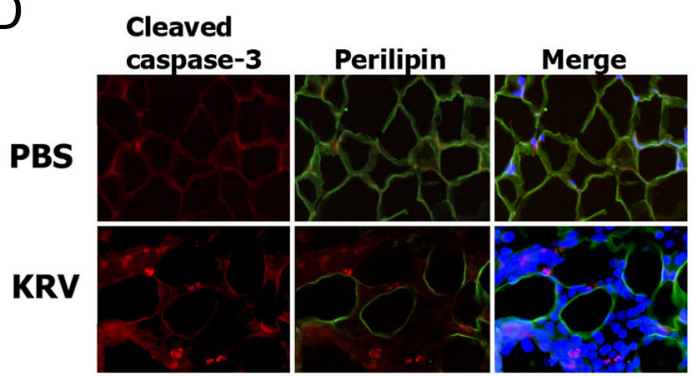

$E$

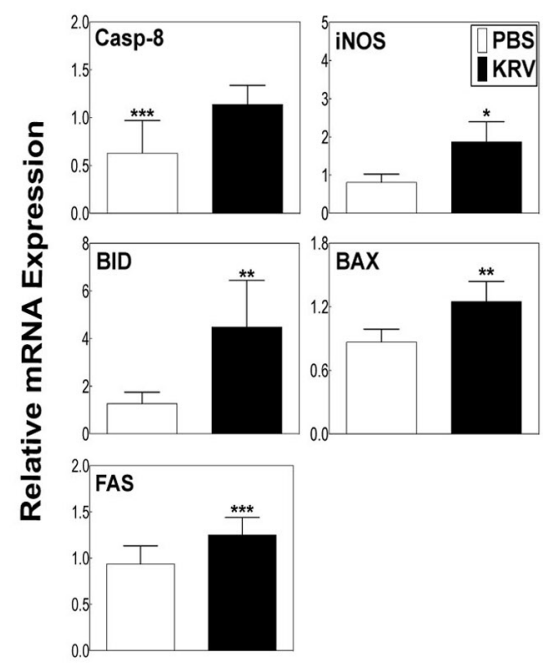

Figure 5

Virus infection leads to apoptosis in visceral adipose tissue. LEW1.WR1 rats were injected i.p. with PBS or KRV and visceral adipose tissue and pancreases were removed 5 days following virus inoculation $(n=3-5)$. Shown are immunofluorescence images of adipose tissue sections stained with an antibody against Perilipin A (red), TUNEL (green) and DAPI (blue) (Panel A) and sections stained with antibodies against CD68 (red), TUNEL (green) and DAPI (blue) (Panel B). Images shown in Panel C represent pancreatic sections stained with antibodies against insulin (red), TUNEL (green) and DAPI (blue). Images shown in Panel D represent adipose tissue stained with antibodies against activated caspase-3 (red) and Perilipin A (green) and DAPI (blue). Merge 1 and merge 2 represent the co-localization of red and green vs red, green and blue staining, respectively. All immunofluorescence images shown were obtained using a $\times 20$ objective. Panel $\mathrm{E}$ demonstrates the expression level of transcripts for genes associated with apoptosis evaluated by quantitative RT-PCR $(n=5-6)$. Histological sections shown are representative of images obtained from 3 to 5 independent experiments. Bars represent mean values \pm S.D. Statistical analysis was performed using an unpaired Student's $t$-test. ${ }^{*} P<0.001 ; * * P<0.01 ; * * * P<0.05$. KRV, Kilham rat virus. A full color version of this figure is available at https://doi.org/10.1530/JOE-18-0131.

on adipose tissue functionality $(n=3-6)$. To do so, we first assessed the expression level of adipokines. Quantitative RT-PCR analysis performed in tissue from day 5-infected vs uninfected rats demonstrated a four- to eight-fold decrease in the level of transcripts for adiponectin (Adipoq), leptin (Lep), PPAR $($ Pparg) $(P<0.001$ for all three genes) and resistin (Retn) $(P<0.05)$ (Fig. 6A). Innate immune activation with Poly (I:C) in the absence of KRV also led to a reduction in the level of adipokine gene expression on day 5 post treatment (Fig. 6A). In contrast, KRV does not induce differences in the level of adipokine expression in subcutaneous adipose tissue on day 5 following virus inoculation (not shown). Consistent with the RT-PCR data, an approximately ten-fold decrease in adiponectin protein levels was observed in visceral adipose tissue lysates from infected vs uninfected rats $(P<0.001$, Fig. $6 \mathrm{~B}$ and $\mathrm{C})$.

A reduction in the levels of molecules involved in insulin signaling in visceral adipose tissue has been linked to increased risk for T2D development (Smith 2002, Rotter et al. 2003, Friedrich et al. 2012, Boucher et al. 2014). Quantitative RT-PCR was used to test the hypothesis that KRV interferes with the expression of genes associated with mediating insulin signaling pathways. We found a two- to three-fold reduction in the level of mRNA for molecules associated with mediating insulin signaling, 
A

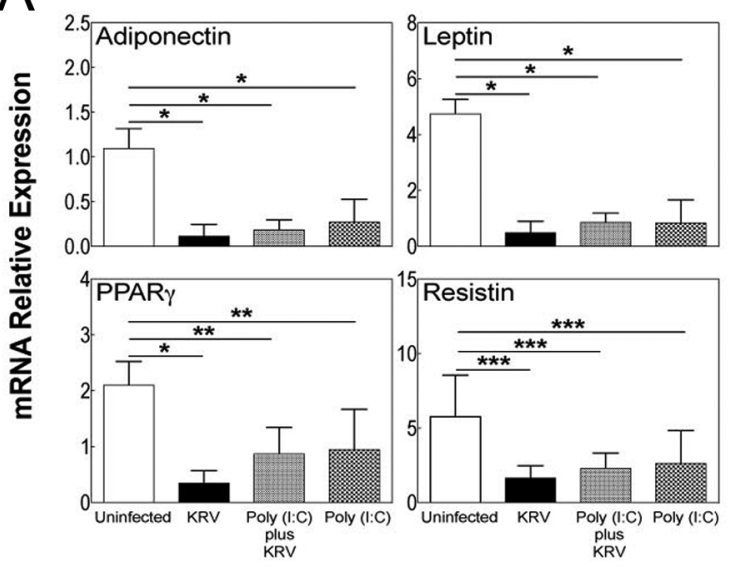

C

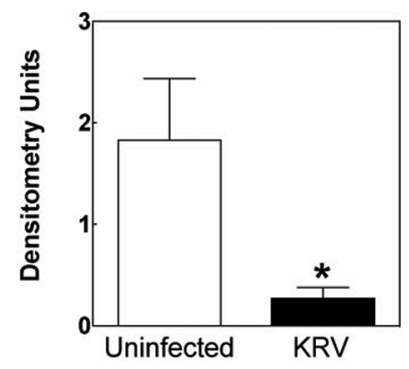

B

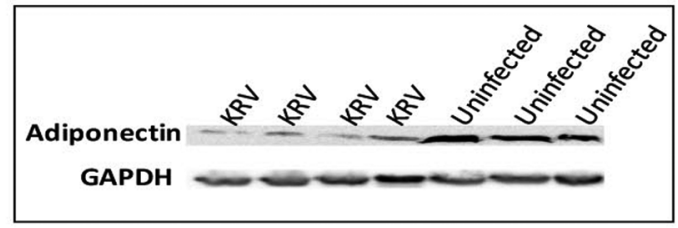

D

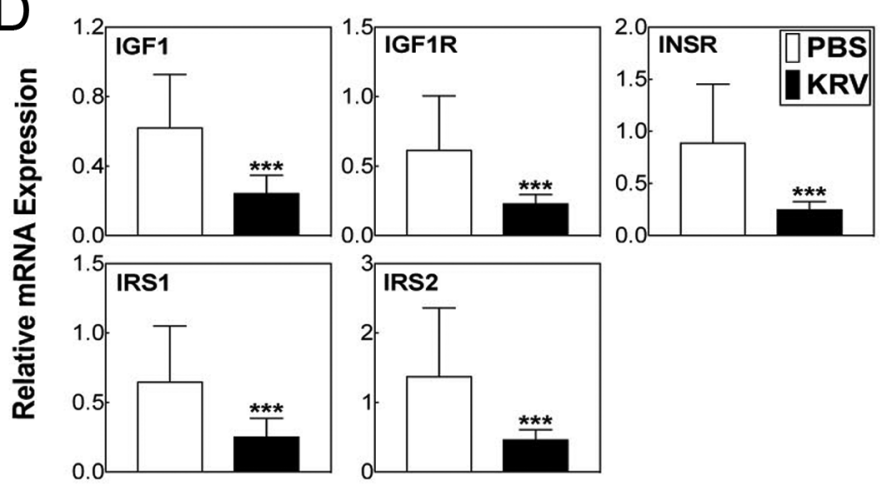

Figure 6

KRV infection downregulates the expression of adipokines and genes associated with mediating insulin signaling. Rats were injected with PBS, treated with KRV, administered Poly $(\mathrm{I}: C)$ or were given Poly $(\mathrm{I}: \mathrm{C})$ plus KRV, and visceral adipose tissue was removed on day 5 post treatment $(n=3-6)$. The level of adipokine transcripts was evaluated by quantitative RT-PCR (A). Western blotting was used to assess adiponectin protein expression levels in tissue lysates using polyclonal rabbit anti-adiponectin and anti-GAPDH Abs (B), and the intensity of each protein band was quantified by densitometry and normalized to its corresponding GAPDH value (C). Panel D demonstrates the expression level of transcripts for genes associated with mediating insulin signaling evaluated by quantitative RT-PCR $(n=6)$. The RT-PCR and densitometry data are presented as the mean \pm s.D. Multiple groups were compared using one- or two-way ANOVA with the Bonferroni post-test. Two group comparisons were performed using an unpaired Student's $t$-test. *** $P<0.05$. KRV, Kilham rat virus.

i.e., insulin-like growth factor 1 (Igf1), IGF1 receptor (Igf1r), insulin receptor (Insr), insulin receptor substrate-1 (Irs1) and insulin receptor substrate 2 (Irs2) $(P<0.05)$ in visceral adipose tissue from infected vs uninfected control animals (Fig. 5).

Together, these data suggest that infection with KRV leads to dysregulated expression of adipokines and insulin signaling molecules in the visceral adipose tissue of LEW1. WR1 rats.

\section{Brief steroid therapy prevents visceral adipose tissue inflammation and diabetes}

We performed proof-of-concept studies to address the hypothesis that attenuation of virus-induced innate immunity can protect from adipose tissue inflammation and diabetes development. To do so, we analyzed the effect of therapy with the corticosteroid dexamethasone on the course of virus-induced disease and adipose tissue inflammation. LEW1.WR1 rats were administered $3 \mu \mathrm{g} / \mathrm{g}$ body weight of Poly (I:C) on three consecutive days and were infected with KRV on the following day (Zipris et al. 2005). Treating rats with Poly (I:C) plus KRV leads to $\beta$ cell inflammation prior to hyperglycemia (Zipris 2011). Rats were then left without any further treatment or were administered $0.2 \mu \mathrm{g} / \mathrm{g}$ body weight of dexamethasone intraperitoneally on 5 consecutive days beginning on the day of infection, as we recently published (Londono et al. 2010). Visceral adipose tissue was removed on day 5 post infection. The results shown in Fig. 7A indicate that treatment with Poly (I:C) plus KRV leads to diabetes in $90 \%$ of the infected animals. In sharp contrast, treatment with Poly (I:C) plus KRV and therapy with dexamethasone on 5 consecutive days beginning on the day of infection 


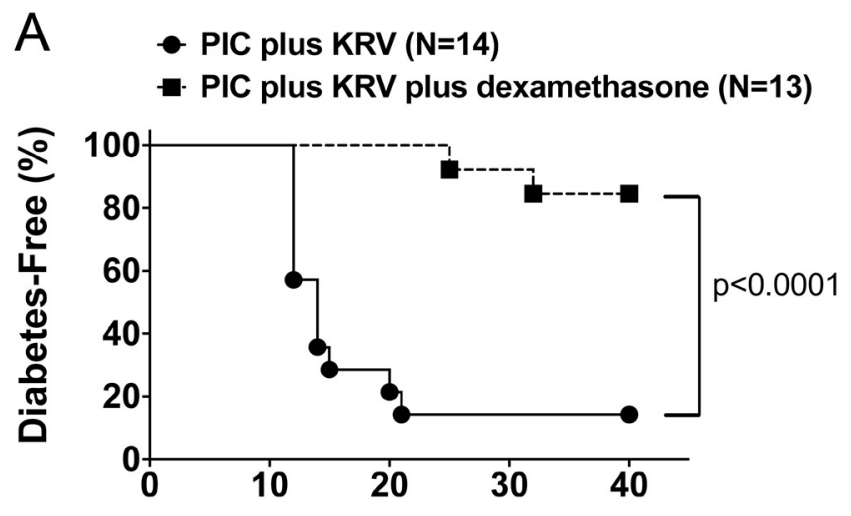

Days After Infection

B

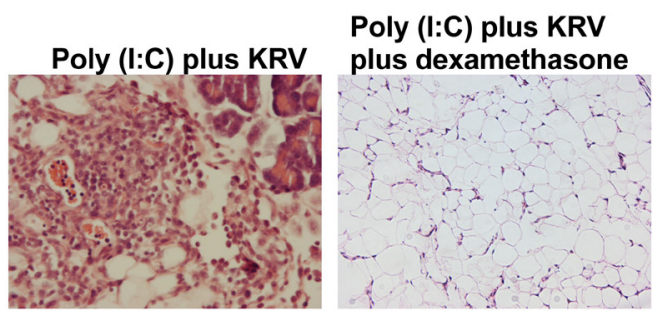

Figure 7

Brief dexamethasone therapy downregulates visceral adipose tissue inflammation and T1D. LEW1.WR1 rats were injected with KRV $(n=13)$ or were treated with Poly $(\mathrm{I}: \mathrm{C})$ plus KRV $(n=14)$. Animals were either left untreated or injected with $2 \mu \mathrm{g} / \mathrm{g}$ body weight of dexamethasone on 5 consecutive days beginning on the day of infection. Animals were tested for diabetes for 40 days following KRV infection. Diabetes was defined as the presence of a plasma glucose concentrations $>250 \mathrm{mg} / \mathrm{dL}(11.1 \mathrm{mM} / \mathrm{L})$ on 2 consecutive days. Survival and statistical comparisons of diabetesfree survival among groups were performed using the Kaplan and Meier method (A). Shown in panel B are paraffin sections of hematoxylin and eosin-stained sections of visceral adipose tissue removed from dexamethasone-treated and -untreated rats 5 days following infection $(n=3-5)$. Histological sections shown are representative of images obtained from three independent experiments. KRV, Kilham rat virus; T1D, type 1 diabetes. A full color version of this figure is available at https://doi.org/10.1530/JOE-18-0131.

reduced diabetes incidence to $\sim 20 \%(P<0.0001)$. Figure 7B further demonstrates that dexamethasone therapy suppresses KRV-induced inflammation in visceral adipose tissue. The data indicate that a brief therapy with low-dose dexamethasone can prevent virus-induced adipose tissue inflammation and diabetes raising the hypothesis that the mechanism of T1D development may be associated, at least in part, with inflammation in visceral adipose tissue.

\section{Discussion}

Adipose tissue has long been known to play pivotal roles in energy and lipid storage. However, emerging data have implied that in addition to its endocrine function, adipose tissue is also an immunologically active organ (Schell et al. 2002, Wen et al. 2014). Moreover, emerging data have implicated adipose tissue inflammation and dysfunction in mechanisms leading to T2D (Donath et al. 2005, Donath \& Shoelson 2011, Donath 2013, 2014). In the present study, we provide for the first time evidence supporting the hypothesis that adipose tissue inflammation and dysfunction may be involved in virusinduced T1D progression in the LEW1.WR1 rat model.

Our data are in agreement with our recent observations linking KRV-induced innate immunity with the development T1D (Londono et al. 2010, Hara et al. 2012, 2013, 2014, Needell et al. 2017). Moreover, our proof-of-concept studies presented herein suggest that attenuation of adipose tissue inflammation with steroid therapy protects from $\beta$ cell autoimmunity. However, because steroids are non-specific suppressors of both innate and adaptive immunity and can exert their antiinflammatory effects on various tissues (Londono et al. 2010), our data do not provide a conclusive evidence for cause-and-effect relationship between adipose tissue inflammation and T1D development. In any case, our data are highly reminiscent of earlier findings from obesity and $\mathrm{T} 2 \mathrm{D}$, in which visceral adipose tissue inflammation has been implicated in promoting dysregulated glucose homeostasis and diabetes (Donath 2013, 2014). Indeed, one of the main characteristics of obesity and T2D is a state of low-grade chronic inflammation detected in visceral but not subcutaneous adipose tissue associated with macrophage recruitment and the induction of proinflammatory immune mediators (Spiegelman et al. 1995, Berg \& Bonner 2005, Odegaard \& Chawla 2008, Donath \& Shoelson 2011, Donath 2014).

We have obtained indirect evidence supporting the hypothesis that KRV induces apoptotic cell death in visceral adipocytes. Indeed, the positive staining for TUNEL and active caspase-3 observed in visceral adipose tissue is not associated with macrophages (this manuscript and data not shown). Moreover, the distribution of TUNEL and active caspase- 3 in close proximity to Perilipin A and the aberrant adipose tissue function observed further support the possibility that the apoptotic cell death observed in adipose tissue is associated with adipocytes.

How inflamed and dysfunctional adipose tissue leads to T1D in the LEW1.WR1 rat remains to be investigated. Available data demonstrate that visceral adipose tissue plays a central role in the mechanism leading to systemic inflammation and hyperglycemia (Tilg \& Moschen 2006, de Luca \& Olefsky 2008, O’Rourke 2009). 
Inflammation and oxidative stress response have long been postulated to play a crucial role in the development of $\beta$ cell destruction and T1D development (Delmastro \& Piganelli 2011). Our data show that KRV induces oxidative stress response in visceral adipose tissue, as evidenced by the detection of ROS and the upregulation of pathways that promote (versus those that protect) an oxidative response. One potential source of ROS is from macrophages that are recruited and accumulated in visceral adipose tissue following KRV infection. These cells can facilitate the production of ROS by NADPH oxidase 2 expressed in $\mathrm{T}$ cells and macrophages (Han 2016). Work done in obesity and T2D has indicated that inflammation and oxidative stress responses in visceral adipose tissue are entwined processes that promote islet dysfunction and T2D (Turkmen 2017). Oxidative stress could lead to the oxidation of biomolecules, such as lipids, proteins and DNA, facilitating tissue damage, loss of biological functions and/or homeostatic imbalance and apoptosis, ultimately resulting in insulin resistance and $\beta$ cell dysfunction (Newsholme et al. 2016, Turkmen 2017).

One other potential mechanism by which inflammation may contribute to T1D development could be mediated by the exposure of $\beta$ cells to proinflammatory cytokines through the circulation or as a result of the anatomic proximity of visceral adipose to the pancreas. We have reported that infection with KRV induces an increase in the level of proinflammatory cytokines in the blood (Zipris et al. 2005, 2007, Hara et al. 2012). It has been shown that treating $\beta$ cells with IL-1 $\beta$, TNF $\alpha$ and IFN $\gamma$, alone or in combination, results in substantial inhibition of insulin secretion (Cetkovic-Cvrlje \& Eizirik 1994, Fu et al. 2013). Moreover, chronic exposure of $\beta$ cells to IL-1 $\beta$ activates inducible nitric oxide synthase (iNOS), leading to excessive production of nitric oxide (NO) culminating in inhibited ATP synthesis and altered islet function (Wang et al. 2010).

We found that KRV downregulates the expression of genes associated with mediating insulin signaling, a finding previously linked with the risk for insulin resistance and T2D development (Rotter et al. 2003, Friedrich et al. 2012, Boucher et al. 2014). Whether T1D mechanisms in the LEW1.WR1 rat is associated with inflammationinduced alterations in insulin signaling pathways and/or dysregulated glucose metabolism occurring prior to $\beta$ cell inflammation remains to be seen. Our findings show that infected rats have normal weight and glucose metabolism on day 5 post infection, at the time when inflammation is detectable in adipose tissue (data not shown). However, we are unable to exclude the possibility that adipose tissue inflammation interferes with as-yet unknown metabolic pathways that ultimately result in $\beta$ cell inflammation and diabetes.

The data provided in this report indicate that activation of the innate immune system with the viral mimic Poly (I:C) leads to influx of $\mathrm{CD}^{2} 8^{+}$cells expressing p22phox into visceral adipose tissue and downmodulation of adipokine expression on day 5 post treatment. These data suggest that similar effects to those exerted by KRV on visceral adipose tissue may potentially be induced by other viruses during their replication. Our findings are compatible with earlier observations demonstrating that Poly (I:C) inhibits the differentiation of preadipocytes to adipocytes and suppresses the expression of leptin and adiponectin in mature adipocytes in mice (Yu et al. 2014).

The observations showing that KRV infects adipocytes are compatible with previous observations that adipose tissue may be infected by a wide range of viruses such as human immunodeficiency virus (HIV), cytomegalovirus, adenovirus and influenza A viruses (Yu et al. 2014). Interestingly, a link between microbial infections and metabolic syndrome has been suggested in individuals infected with HIV (Stanley \& Grinspoon 2012) and Chagas disease triggered by an infection with Trypanosoma cruzi (Wen et al. 2014). It is not yet clear whether inflammation such as that observed in visceral adipose tissue from KRVinfected rats is linked with mechanisms of T1D progression in genetically susceptible individuals. Enteroviruses as well as other viruses have been implicated in the course of human T1D (Kondrashova \& Hyöty 2014, Morgan \& Richardson 2014, de Beeck \& Eizirik 2016, Lönnrot et al. 2017). Interestingly, earlier studies indicate that similar to $\mathrm{KRV}$, enteroviruses can induce inflammation in visceral adipose tissue in the mouse (Hashimoto et al. 1985, Gay et al. 2006).

Although earlier studies have shown that multiple routes of KRV injection can lead to systemic virus infection (Novotny \& Hetrick 1970) and T1D (Guberski et al. 1991), and administering KRV intraperitoneally induces inflammation in sites proximal and distal to the site of virus inoculation (Hara et al. 2012), we have not tested whether the KRV-induced inflammation seen in visceral adipose tissue is a phenomenon associated with the specific virus inoculation route used in our studies.

In summary, our studies provide new evidence raising the hypothesis that visceral adipose tissue inflammation may be linked with the development of virus-induced $\beta$ cell autoimmunity in the LEW1.WR1 rat model. Key outstanding questions remain to be investigated. For example, is there a cause-and-effect relationship between 
virus-induced visceral adipose tissue inflammation and T1D. Likewise, what are the specific proinflammatory pathways and cytokines associated with the mechanisms by which adipose tissue inflammation contributes to $\beta$ cell autoimmunity; what is the role of visceral adipose tissue inflammation vs systemic inflammation in disease progression; and how oxidative stress pathways and apoptosis are involved in $\beta$ cell destruction. A better understanding of the role of innate immune activation in the early onset of T1D could lead to new target molecules to prevent islet autoimmunity in genetically susceptible individuals.

\section{Declaration of interest}

The authors declare that there is no conflict of interest that could be perceived as prejudicing the impartiality of the research reported.

\section{Funding}

This research did not receive any specific grant from any funding agency in the public, commercial or not-for-profit sector.

\section{Author contribution statement}

James C Needell and Madalyn N Brown performed the in vitro and in vivo experiments detailed in this report. Danny Zipris oversaw the project and wrote the manuscript and is the guarantor of this work and, as such, had full access to all the data in the study and takes responsibility for the integrity of the data and the accuracy of the data analysis.

\section{References}

Aggarwal BB 2003 Signalling pathways of the TNF superfamily: a doubleedged sword. Nature Reviews: Immunology 3 745-756. (https://doi. org/10.1038/nri1184)

Albina JE, Cui S, Mateo RB \& Reichner JS 1993 Nitric oxide-mediated apoptosis in murine peritoneal macrophages. Journal of Immunology 150 5080-5085.

Alkhouri N, Gornicka A, Berk MP, Thapaliya S, Dixon LJ, Kashyap S, Schauer PR \& Feldstein AE 2010 Adipocyte apoptosis, a link between obesity, insulin resistance, and hepatic steatosis. Journal of Biological Chemistry 285 3428-3438. (https://doi.org/10.1074/jbc.M109.074252)

Arstall MA, Sawyer DB, Fukazawa R \& Kelly RA 1999 Cytokine-mediated apoptosis in cardiac myocytes. Role of inducible nitric oxide synthase induction and peroxynitrite generation. Circulation Research $\mathbf{8 5}$ 829-840.

Atkinson MA, Eisenbarth GS \& Michels AW 2014 Type 1 diabetes. Lancet 383 69-82. (https://doi.org/10.1016/S0140-6736(13)60591-7)

Berg A \& Bonner G 2005 Obesity and cardiovascular morbidity - a comment of the National Heart and Circulation Conference (NHKK). Deutsche Medizinische Wochenschrift 130 893-897. (https://doi. org/10.1055/s-2005-865104)

Blüher M 2013 Adipose tissue dysfunction contributes to obesity related metabolic diseases. Best Practice and Research Clinical Endocrinology and Metabolism 27 163-177.
Boucher J, Kleinridders A \& Kahn CR 2014 Insulin receptor signaling in normal and insulin-resistant states. Cold Spring Harbor Perspectives in Biology 6 a009191. (https://doi.org/10.1101/cshperspect.a009191)

Brune B 2003 Nitric oxide: NO apoptosis or turning it ON? Cell Death and Differentiation 10 864-869. (https://doi.org/10.1038/sj.cdd.4401261)

Casbon A-J, Allen L-AH, Dunn KW \& Dinauer MC 2009 Macrophage NADPH oxidase flavocytochrome b localizes to the plasma membrane and Rab11-positive recycling endosomes. Journal of Immunology 182 2325-2339. (https://doi.org/10.4049/jimmunol.0803476)

Cetkovic-Cvrlje M \& Eizirik DL 1994 TNF- $\alpha$ and IFN- $\gamma$ potentiate the deleterious effects of IL- $1 \beta$ on mouse pancreatic islets mainly via generation of nitric oxide. Cytokine 6 399-406. (https://doi. org/10.1016/1043-4666(94)90064-7)

Cheng EHYA, Wei MC, Weiler S, Flavell RA, Mak TW, Lindsten T \& Korsmeyer SJ 2001 BCL-2, BCL-XL sequester BH3 domain-only molecules preventing BAX- and BAK-mediated mitochondrial apoptosis. Molecular Cell 8 705-711. (https://doi.org/10.1016/S10972765(01)00320-3)

de Beeck AO \& Eizirik DL 2016 Viral infections in type 1 diabetes mellitus - why the $\beta$ cells? Nature Reviews: Endocrinology 12 263-273.

de Luca C \& Olefsky JM 2008 Inflammation and insulin resistance. FEBS Letters 582 97-105. (https://doi.org/10.1016/j.febslet.2007.11.057)

Delmastro MM \& Piganelli JD 2011 Oxidative stress and redox modulation potential in type 1 diabetes. Clinical and Developmental Immunology 2011593863.

Desagher S, Osen-Sand A, Nichols A, Eskes R, Montessuit S, Lauper S, Maundrell K, Antonsson B \& Martinou J-C 1999 Bid-induced conformational change of bax is responsible for mitochondrial cytochrome C release during apoptosis. Journal of Cell Biology 144 891-901. (https://doi.org/10.1083/jcb.144.5.891)

Donath MY 2013 When metabolism met immunology. Nature Immunology 14 421-422. (https://doi.org/10.1038/ni.2591)

Donath MY 2014 Targeting inflammation in the treatment of type 2 diabetes: time to start. Nature Reviews Drug Discovery 13 465-476. (https://doi.org/10.1038/nrd4275)

Donath MY \& Shoelson SE 2011 Type 2 diabetes as an inflammatory disease. Nature Reviews: Immunology 11 98-107.

Donath MY, Ehses JA, Maedler K, Schumann DM, Ellingsgaard H, Eppler E \& Reinecke M 2005 Mechanisms of $\beta$-cell death in type 2 diabetes. Diabetes 54 S108-S113. (https://doi.org/10.2337/diabetes.54.suppl_2.S108)

Espinosa-Diez C, Miguel V, Mennerich D, Kietzmann T, Sánchez-Pérez P, Cadenas S \& Lamas S 2015 Antioxidant responses and cellular adjustments to oxidative stress. Redox Biology 6 183-197. (https://doi. org/10.1016/j.redox.2015.07.008)

Friedrich N, Thuesen B, Jørgensen T, Juul A, Spielhagen C, Wallaschofksi H \& Linneberg A 2012 The association between IGF-I and insulin resistance. A general population study in Danish adults. Diabetes Care 35 768-773. (https://doi.org/10.2337/dc11-1833)

Fu Z, Gilbert ER \& Liu D 2013 Regulation of insulin synthesis and secretion and pancreatic beta-cell dysfunction in diabetes. Current Diabetes Reviews 9 25-53. (https://doi. org/10.2174/157339913804143225)

Furukawa S, Fujita T, Shimabukuro M, Iwaki M, Yamada Y, Nakajima Y, Nakayama O, Makishima M, Matsuda M \& Shimomura I 2004 Increased oxidative stress in obesity and its impact on metabolic syndrome. Journal of Clinical Investigation 114 1752-1761. (https:// doi.org/10.1172/JCI21625)

Gay RT, Belisle S, Beck MA \& Meydani SN 2006 An aged host promotes the evolution of avirulent coxsackievirus into a virulent strain. PNAS 103 13825-13830. (https://doi.org/10.1073/pnas.0605507103)

Guberski DL, Thomas VA, Shek WR, Like AA, Handler ES, Rossini AA, Wallace JE \& Welsh RM 1991 Induction of type I diabetes by Kilham's rat virus in diabetes-resistant BB/Wor rats. Science 254 1010-1013. (https://doi.org/10.1126/science.1658938)

Haase J, Weyer U, Immig K, Kloting N, Bluher M, Eilers J, Bechmann I \& Gericke M 2014 Local proliferation of macrophages in adipose tissue 
during obesity-induced inflammation. Diabetologia 57 562-571. (https://doi.org/10.1007/s00125-013-3139-y)

Han CY 2016 Roles of reactive oxygen species on insulin resistance in adipose tissue. Diabetes and Metabolism Journal 40 272-279.

Han JM \& Levings MK 2013 Immune regulation in obesity-associated adipose inflammation. Journal of Immunology 191 527-532. (https:// doi.org/10.4049/jimmunol.1301035)

Hara N, Alkanani AK, Ir D, Robertson CE, Wagner BD, Frank DN \& Zipris D 2012 Prevention of virus-induced type 1 diabetes with antibiotic therapy. Journal of Immunology 189 3805-3814. (https://doi. org/10.4049/jimmunol.1201257)

Hara N, Alkanani A, Dinarello C \& Zipris D 2013 Histone deacetylase inhibitor suppresses virus-induced proinflammatory responses and type 1 diabetes. Journal of Molecular Medicine 92 93-102. (https://doi. org/10.1007/s00109-013-1078-1)

Hara N, Alkanani AK, Dinarello CA \& Zipris D 2014 Modulation of virusinduced innate immunity and type 1 diabetes by IL-1 blockade. Innate Immunity 20 574-584. (https://doi.org/10.1177/1753425913502242)

Hashimoto I, Tomita M, Kohara T, Uchino I \& Harasima A 1985 Steatitis in mice infected with coxsackie virus B3. Microbiology and Immunology 29 371-376. (https://doi.org/10.1111/j.1348-0421.1985.tb00836.x)

Hong C-P, Yun CH, Lee G-W, Park A, Kim Y-M \& Jang MH 2015 TLR9 regulates adipose tissue inflammation and obesity-related metabolic disorders. Obesity 23 2199-2206. (https://doi.org/10.1002/oby.21215)

Hotamisligil GS, Arner P, Caro JF, Atkinson RL \& Spiegelman BM 1995 Increased adipose-tissue expression of tumor-necrosis-factor-alpha in human obesity and insulin-resistance. Journal of Clinical Investigation 95 2409-2415. (https://doi.org/10.1172/JCI117936)

Budihardjo I, Oliver H, Lutter M, Luo X \& Wang X 1999 Biochemical pathways of caspase activation during apoptosis. Annual Review of Cell and Developmental Biology 15 269-290. (https://doi.org/10.1146/ annurev.cellbio.15.1.269)

Kishimoto K, Sandner S, Imitola J, Sho M, Li Y, Langmuir PB, Rothstein DM, Strom TB, Turka LA \& Sayegh MH 2002 Th1 cytokines, programmed cell death, and alloreactive $\mathrm{T}$ cell clone size in transplant tolerance. Journal of Clinical Investigation 109 1471-1479. (https://doi. org/10.1172/JCI0214947)

Kondrashova A \& Hyöty H 2014 Role of viruses and other microbes in the pathogenesis of type 1 diabetes. International Reviews of Immunology 33 284-295. (https://doi.org/10.3109/08830185.2014.889130)

Londono P, Komura A, Hara N \& Zipris D 2010 Brief dexamethasone treatment during acute infection prevents virus-induced autoimmune diabetes. Clinical Immunology 135 401-411. (https://doi.org/10.1016/j. clim.2010.01.007)

Lönnrot M, Lynch KF, Elding Larsson H, Lernmark Å, Rewers MJ, Törn C, Burkhardt BR, Briese T, Hagopian WA, She J-X, et al. 2017 Respiratory infections are temporally associated with initiation of type 1 diabetes autoimmunity: the TEDDY study. Diabetologia 60 1931-1940.

Matsumoto T, Kano K, Kondo D, Fukuda N, Iribe Y, Tanaka N, Matsubara Y, Sakuma T, Satomi A, Otaki M, et al. 2008 Mature adipocyte-derived dedifferentiated fat cells exhibit multilineage potential. Journal of Cellular Physiology 215 210-222. (https://doi. org/10.1002/jcp.21304)

Mittendorfer B 2011 Origins of metabolic complications in obesity: adipose tissue and free fatty acid trafficking. Current Opinion in Clinical Nutrition and Metabolic Care 14 535-541. (https://doi.org/10.1097/ MCO.0b013e32834ad8b6)

Mordes JP, Bortell R, Blankenhorn EP, Rossini AA \& Greiner DL 2004 Rat models of type 1 diabetes: genetics, environment, and autoimmunity. ILAR Journal 45 278-291. (https://doi.org/10.1093/ilar.45.3.278)

Morgan NG \& Richardson SJ 2014 Enteroviruses as causative agents in type 1 diabetes: loose ends or lost cause? Trends in Endocrinology and Metabolism 25 611-619. (https://doi.org/10.1016/j.tem.2014.08.002)

Needell JC, Ir D, Robertson CE, Kroehl ME, Frank DN \& Zipris D 2017 Maternal treatment with short-chain fatty acids modulates the intestinal microbiota and immunity and ameliorates type 1 diabetes in the offspring. PLOS ONE 12 e0183786. (https://doi.org/10.1371/ journal.pone.0183786)

Newsholme P, Cruzat VF, Keane KN, Carlessi R \& de Bittencourt PIH 2016 Molecular mechanisms of ROS production and oxidative stress in diabetes. Biochemical Journal 473 4527-4550. (https://doi. org/10.1042/BCJ20160503C)

Nikoletopoulou V, Markaki M, Palikaras K \& Tavernarakis N 2013 Crosstalk between apoptosis, necrosis and autophagy. Biochimica et Biophysica Acta (BBA): Molecular Cell Research 1833 3448-3459. (https://doi.org/10.1016/j.bbamcr.2013.06.001)

Novotny JF \& Hetrick FM 1970 Pathogenesis and transmission of kilham rat virus infection in rats. Infection and Immunity 2 298-303.

O'Rourke RW 2009 Inflammation in obesity-related disease. Surgery 145 255-259.

Odegaard JI \& Chawla A 2008 Mechanisms of macrophage activation in obesity-induced insulin resistance. Nature Clinical Practice: Endocrinology and Metabolism 4 619-626. (https://doi.org/10.1038/ ncpendmet0976)

Olagnier D, Peri S, Steel C, van Montfoort N, Chiang C, Beljanski V, Slifker M, He Z, Nichols CN, Lin R, et al. 2014 Cellular oxidative stress response controls the antiviral and apoptotic programs in dengue virus-infected dendritic cells. PLoS Pathogens 10 e1004566. (https:// doi.org/10.1371/journal.ppat.1004566)

Picklo M, Claycombe KJ \& Meydani M 2012 Adipose dysfunction, interaction of reactive oxygen species, and inflammation. Advances in Nutrition 3 734-735. (https://doi.org/10.3945/an.112.002626)

Reshi ML, Su Y-C \& Hong J-R 2014 RNA viruses: ROS-mediated cell death. International Journal of Cell Biology 2014 16. (https://doi. org/10.1155/2014/467452)

Romacho T, Elsen M, Röhrborn D \& Eckel J 2014 Adipose tissue and its role in organ crosstalk. Acta Physiologica 210 733-753. (https://doi. org/10.1111/apha.12246)

Rotter V, Nagaev I \& Smith U 2003 Interleukin-6 (IL-6) induces insulin resistance in 3T3-L1 adipocytes and is, like IL-8 and tumor necrosis factor- $\alpha$, overexpressed in human fat cells from insulin-resistant subjects. Journal of Biological Chemistry 278 45777-45784. (https://doi. org/10.1074/jbc.M301977200)

Roulston A, Marcellus RC \& Branton PE 1999 Viruses and apoptosis. Annual Review of Microbiology 53 577-628. (https://doi.org/10.1146/ annurev.micro.53.1.577)

Sarih M, Souvannavong V \& Adam A 1993 Nitric oxide synthase induces macrophage death by apoptosis. Biochemical and Biophysical Research Communications 191 503-508. (https://doi.org/10.1006/ bbrc.1993.1246)

Schäffler A \& Schölmerich J 2010 Innate immunity and adipose tissue biology. Trends in Immunology 31 228-235.

Schell MA, Karmirantzou M, Snel B, Vilanova D, Berger B, Pessi G, Zwahlen MC, Desiere F, Bork P, Delley M, et al. 2002 The genome sequence of Bifidobacterium longum reflects its adaptation to the human gastrointestinal tract. PNAS 99 14422-14427. (https://doi. org/10.1073/pnas.212527599)

Smith U 2002 Impaired ('diabetic') insulin signaling and action occur in fat cells long before glucose intolerance - is insulin resistance initiated in the adipose tissue? International Journal of Obesity 26 897. (https:// doi.org/10.1038/sj.ijo.0802028)

Spiegelman BM, Arner P, Caro JF, Atkinson RL \& Hotamisligil GS 1995 Elevation of adipose-tissue expression of Tnf-alpha and Tnf receptors in human obesity and insulin-resistance. Diabetes $\mathbf{4 4}$ A45-A45.

Stanley TL \& Grinspoon SK 2012 Body composition and metabolic changes in HIV-infected patients. Journal of Infectious Diseases 205 S383-S390. (https://doi.org/10.1093/infdis/jis205)

Strasser A, Cory S \& Adams JM 2011 Deciphering the rules of programmed cell death to improve therapy of cancer and other diseases. EMBO Journal 30 3667-3683. (https://doi.org/10.1038/ emboj.2011.307) 
Tilg H \& Moschen AR 2006 Adipocytokines: mediators linking adipose tissue, inflammation and immunity. Nature Reviews: Immunology 6 $772-783$.

Turkmen K 2017 Inflammation, oxidative stress, apoptosis, and autophagy in diabetes mellitus and diabetic kidney disease: the Four Horsemen of the Apocalypse. International Urology and Nephrology 49 837-844. (https://doi.org/10.1007/s11255-016-1488-4)

Wang C, Guan Y \& Yang J 2010 Cytokines in the progression of pancreatic $\beta$-cell dysfunction. International Journal of Endocrinology 2010 10. (https://doi.org/10.1155/2010/515136)

Wei MC, Lindsten T, Mootha VK, Weiler S, Gross A, Ashiya M, Thompson CB \& Korsmeyer SJ 2000 tBID, a membrane-targeted death ligand, oligomerizes BAK to release cytochrome C. Genes and Development 14 2060-2071.

Wen J-J, Nagajyothi F, Machado F, Weiss L, Scherer P, Tanowitz H \& Garg N 2014 Markers of oxidative stress in adipose tissue during Trypanosoma cruzi infection. Parasitology Research 113 3159-3165. (https://doi.org/10.1007/s00436-014-3977-7)

Wolter TR, Wong R, Sarkar SA \& Zipris D 2009 DNA microarray analysis for the identification of innate immune pathways implicated in virus-induced autoimmune diabetes. Clinical Immunology 132 103-115. (https://doi.org/10.1016/j.clim.2009.02.007)

Yu L, Yan K, Liu P, Li N, Liu Z, Zhu W, Chen Y \& Han D 2014 Pattern recognition receptor-initiated innate antiviral response in mouse adipose cells. Immunology and Cell Biology 92 105-115. (https://doi. org/10.1038/icb.2013.66)

Zipris D 2011 Innate immunity in type 1 diabetes. Diabetes/Metabolism Research and Reviews 27 824-829. (https://doi.org/10.1002/dmrr.1256)

Zipris D, Lien E, Xie JX, Greiner DL, Mordes JP \& Rossini AA 2005 TLR activation synergizes with kilham rat virus infection to induce diabetes in BBDR rats. Journal of Immunology 174 131-142. (https:// doi.org/10.4049/jimmunol.174.1.131)

Zipris D, Lien E, Nair A, Xie JX, Greiner DL, Mordes JP \& Rossini AA 2007 TLR9-signaling pathways are involved in Kilham rat virus-induced autoimmune diabetes in the biobreeding diabetes-resistant rat. Journal of Immunology 178 693-701. (https://doi.org/10.4049/jimmunol.178.2.693)

Zong W-X, Lindsten T, Ross AJ, MacGregor GR \& Thompson CB 2001 $\mathrm{BH} 3$-only proteins that bind pro-survival Bcl-2 family members fail to induce apoptosis in the absence of Bax and Bak. Genes and Development 15 1481-1486. (https://doi.org/10.1101/gad.897601)

Received in final form 3 May 2018

Accepted 8 May 2018

Accepted Preprint published online 9 May 2018 (c) 2018 Society for Endocrinology Published by Bioscientifica Ltd. 